\title{
Total Number of Prostate Tissue Cores
}

National Cancer Institute

\section{Source}

National Cancer Institute. Total Number of Prostate Tissue Cores. NCI Thesaurus. Code C148277.

An indication of the total number of prostate core specimens collected during a biopsy procedure. 